\title{
The role of cytotoxic macrophages in non-obese diabetic mice: cytotoxicity against murine mastocytoma and beta-cell lines
}

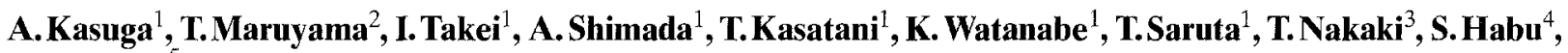 \\ J. Miyazaki ${ }^{5}$ \\ ${ }^{1}$ Department of Internal Medicine, Keio University, School of Medicine, Tokyo, Japan \\ ${ }^{2}$ Department of Internal Medicine, Social Insurance Saitama Chuo Hospital, Saitama, Japan \\ ${ }^{3}$ Department of Pharmacology, Keio University, School of Medicine, Tokyo, Japan \\ ${ }^{4}$ Department of Immunology, Tokai University, School of Medicine, Kanagawa, Japan \\ ${ }^{5}$ Department of Disease-Related Gene Regulation Research (Sandoz), Faculty of Medicine, University of Tokyo, Tokyo, Japan
}

\begin{abstract}
Summary. The cytotoxicity of macrophages from non-obese diabetic (NOD) mice against murine mastocytoma (P-815), and murine beta-cell lines having the NOD gene background (MIN6N-9a), were examined. Peritoneal exudate cells from 20-week-old mice showed higher cytotoxicity, measured as inhibition of thymidine uptake into P-815, than those from 12-week-old mice $(p<0.01)$. In cyclophosphamide-injected mice, cytotoxicity of peritoneal exudate cells had increased at 8 days post-injection, at which time the mice were not diabetic. To confirm macrophage cytotoxicity against pancreatic cells and examine its cytolytic mechanism, the cytotoxicity of peritoneal exudate cells from cyclophosphamideinjected NOD mice against MIN6N-9a cells was measured by the chromium release assay. These peritoneal exudate cells showed higher cytotoxicity as compared to those of saline-injected mice $(p<0.001)$. Macrophages were demonstrated to
\end{abstract}

be the major component of peritoneal exudate cells (50\%) by flowcytometric analyses. Cytotoxicity increased with macrophage enrichment by adhesion $(p<0.01)$. Furthermore, a macrophage toxin, silica, completely blocked the cytotoxicity $(p<0.001)$. Cytokines (interleukin 1 and tumour necrosis factor) and a nitric-oxide-producing vasodilator, sodium nitroprusside, were cytotoxic to MIN6N-9a cells but only sodium nitroprusside showed cytotoxicity when incubated for the same period as peritoneal exudate cells. Thus, macrophages play an important role in beta-cell destruction and soluble factors other than cytokines (e.g. nitric oxide) may be mediators of this early cytolytic process.

Key words: Non-obese diabetic mice, macrophage, Type 1 (insulin-dependent) diabetes mellitus, cytokine, nitric oxide.
Non-obese diabetic (NOD) mice spontaneously develop a diabetic syndrome which, in many respects, resembles human Type 1 (insulin-dependent) diabetes mellitus [1]. Before the onset of diabetes, many mononuclear cells appear in the islets of Langerhans, and it is hypothesized that the diabetic syndrome in NOD mice results from the destruction of pancreatic beta cells by cell-mediated immune responses [2-8].

Recently, investigators have reported that artificiallyactivated macrophages have cytotoxicity against pancreatic islet cells [9] and that macrophage-related soluble mediators, such as cytokines [10-12] (interleukin 1 and tumour necrosis factor), oxygen free radicals [13,14], nitric oxide $[15,16]$, serine protease [17] and eicosanoids [18], have cytotoxic activity against beta cells. It has not, however, been determined whether macrophages from diabetic animals are cytotoxic to pancreatic beta cells.

In addition, some reports have indicated that inhibition of macrophage function will prevent the development of diabetes [19-21] and, recently, adoptive transfer experi- ments have shown that peritoneal macrophages from diabetic NOD mice can transfer the disease to irradiated [22] or young [23] NOD mice. These peritoneal macrophages are therefore thought to play an important role in the development of diabetes. The mechanism, however, remains to be clarified. To determine the role of macrophages as final effector cells in pancreatic beta-cell destruction, we examined macrophage cytotoxicity against P-815 and murine beta cells and cytotoxicities of macrophage-related soluble mediators against murine beta cells.

\section{Materials and methods}

Animals. Female NOD and ICR (Institute of Cancer Research) mice were purchased from Clea Japan Inc. (Tokyo, Japan). They were kept under specific pathogen-free conditions. In some experiments, either cyclophosphamide (CY, $200 \mathrm{mg} / \mathrm{kg}$; Shionogi Pharmaceutical Co. Ltd., Osaka, Japan) or $154 \mathrm{mmol} / \mathrm{l} \mathrm{NaCl}(10 \mathrm{ml} / \mathrm{kg})$ was injected intraperitoneally at 12 weeks of age. For in vivo suppression of macrophage function, silica particles $(0.5-10 \mu \mathrm{m}$, Sigma, St Louis, 


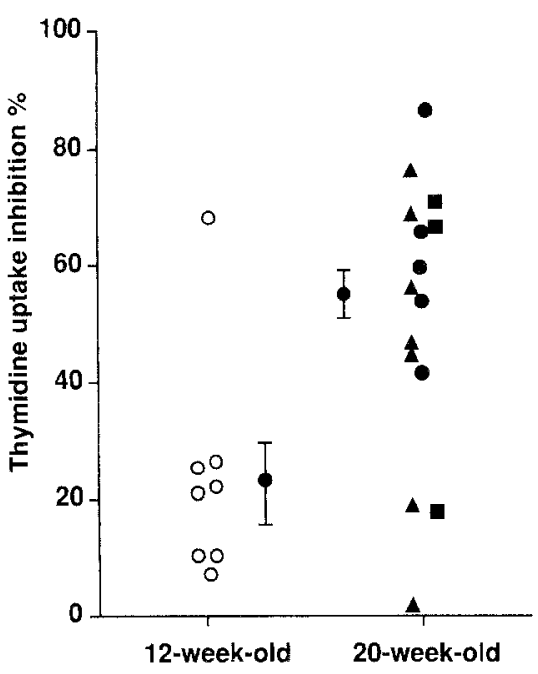

Fig. 1. Cytotoxicity of peritoneal exudate cells (PEC) from NOD mice against the $P-815$ cell. PEC were obtained from $12-(O)$ and 20 (closed symbols) week-old NOD mice and macrophages were enriched on microplates. The 12-week-old mice were all non-diabetic and the 20-week-old mice were separated into non-diabetic (blood glucose $<14.0 \mathrm{mmol} / \mathrm{l}, \mathbf{a}$ ), mildly diabetic (blood glucose 14.9 $33.3 \mathrm{mmol} / \mathrm{l}, \mathbf{0}$ ), and overtly diabetic (blood glucose $>33.3 \mathrm{mmol} / \mathrm{l}$, A) groups. Bars indicate the mean \pm SEM of each group. Maximal uptake was $540,962 \mathrm{cpm}$. The PEC from 20 -week-old mice showed higher cytotoxicity than those from 12 -week-old mice $(p<0.01)$

Mo., USA) were suspended in phosphate-buffered saline $(5 \mathrm{mg} / \mathrm{ml})$ and injected intraperitoneally every 10 days $(20 \mathrm{ml} / \mathrm{kg})$, from 5 weeks of age, on five occasions. Diabetes was diagnosed when urine glucose was positive by Tes Tape (Eli Lilly, Indianapolis, Ind., USA) and blood glucose was above $14.0 \mathrm{mmol} / \mathrm{l}$ by the glucose oxidation method.

Chemicals. Human tumour necrosis factor $\alpha$ (Dainippon Pharmaceutical Co. Ltd., Tokyo, Japan), murine interferon $\gamma$ (Shionogi Pharmaceutical Co., Ltd.), human interleukin-1 $\beta$ (Otsuka Pharmaceutical Co. Ltd., Tokyo, Japan), lipopolysaccharide (E. coli 055:B5; Sigma), a nitric oxide producing vasodilator, sodium nitroprusside (Sigma) [24], rhodanese (Sigma), and sodium thiosulphate (Wako pure chemical industries Ltd., Osaka, Japan) were used.

Target cells. P-815 cells (murine mastocytoma) and a murine betacell line (MIN6N-9a), were used. P-815 cells were generously donated by Dr. Tadakuma (Keio University, Japan). An MIN6N-9a line, which has the same genetic background as the NOD mouse model, was established. IT6 transgenic mice were produced by microinjection of the insulin promotor-SV40 T antigen hybrid gene into fertilized eggs from C57BL/6 [25] and backcrossed to NOD mice. The MIN6N-9a cells lines were established from an insulinoma developed in one of the transgenic mice from the ninth backcross which were NOD homozygous for the $\mathrm{H}-2$. This cell line was shown to retain various properties characteristic of pancreatic beta cells including glucose-inducible insulin secretion $(19 \mathrm{mU}$ and $57.3 \mathrm{mU} / 4 \times 10^{5}$ cells $/ 48 \mathrm{~h}$, at glucose concentrations of $5.5 \mathrm{mmol} / 1$ and $25 \mathrm{mmol} / \mathrm{l}$, respectively). P-815 cell cultures were maintained in RPMI1640 supplemented with $10 \%$ heat-inactivated fetal bovine serum, $1 \times 10^{6}$ units $/ 1$ penicillin, $100 \mathrm{mg} / \mathrm{l} \mathrm{streptomycin,} 100 \mathrm{mg} / \mathrm{l} \mathrm{so-}$ dium pyruvate, $300 \mathrm{mg} / 1$ l-glutamine, $57 \mu \mathrm{mol} / 12$ 2-mercaptoethanol, $0.1 \mathrm{mmol} / \mathrm{l}$ minimal essential medium non-essential amino acid solution, $2 \mathrm{~g} / 1 \mathrm{NaHCO}_{3}$ and $2.38 \mathrm{~g} / \mathrm{l} \mathrm{HEPES}$. Culture of MIN6N-9a cells was maintained in Dulbecco`s minimal essential medium (DMEM) supplemented with the same reagent except that $15 \%$ fetal bovine serum and $3.7 \mathrm{~g} / 1 \mathrm{NaHCO}_{3}$ was used. MIN6N-9a monolayers were dissociated into single cells by $0.25 \%$ trypsin- $1 \mathrm{mmol} / \mathrm{l}$ EDTA-phosphate-buffered saline before use as target cells.
Effector cells. Mice were killed by aspirating blood from the heart under ether anaesthesia. Peritoneal exudate cells (PEC) were harvested by lavage of the peritoneum with culture medium. They were washed three times and resuspended in the culture medium. Macrophage enrichment was done by the adhesion method. Cell suspensions $\left(1 \times 10^{7} / \mathrm{ml}\right)$ were cultured in plastic dishes for $2 \mathrm{~h}\left(37^{\circ} \mathrm{C}, 5 \%\right.$ $\mathrm{CO}_{2}$ ). Non-adherent cells were harvested by washing the dishes with culture medium. Adherent cells were dissociated with $1 \mathrm{mmol} / \mathrm{l}$ EDTA-phosphate-buffered saline and resuspended in culture medium after washing. In some experiments, macrophages were enriched by adhesion to the microculture plate.

${ }^{3} H$-thymidine uptake inhibition test. P-815 cells and effector cells were co-incubated in triplicate in 96-well microculture plates at a target:effector ratio of $10: 1$. The plates were incubated at $37^{\circ} \mathrm{C}$ for $40 \mathrm{~h}$, and pulsed with $1 \mu \mathrm{Ci}^{3} \mathrm{H}$-thymidine (20-40 Ci/mmol; ICN Biomedical Inc., Costa Mesa, Calif., USA) for the final $16 \mathrm{~h}$ in each well. The cells were collected with a cell-harvester. The specific radioactivity was determined by liquid scintillation counting. Inhibition percent was calculated as follows:

$100 \times(1-$ measured cpm/maximal cpm $)$.

${ }^{51} \mathrm{Cr}$ release assay. After MIN6N-9a cells $\left(1-2 \times 10^{4} /\right.$ well) had been cultured on a 96-well microplate for 5-6 days to promote adhesion, $1 \mu \mathrm{Ci}^{51} \mathrm{Cr}$ sodium chromate $(1.2 \mathrm{Ci} / \mathrm{mmol}$; Daiichi radioisotope laboratory, Tokyo, Japan) was added to each well. After 24-h incubation, the plates were washed and cultured with isotope-free medium for 3-4 days. The plates were washed again and co-incubated with effector cells for 16-18 h. In the experiments using macrophage-related soluble mediator, the incubation times ranged from $18-72 \mathrm{~h}$. The supernatant was then collected by means of a supernatant collecting system (Skatron, Lier, Norway) and specific radioactivity was determined by well-type scintillation counting. Percent specific cell lysis was calculated as follows:

$100 \times($ measured $\mathrm{cpm}-$ spontaneous $\mathrm{cpm}) /($ maximal $\mathrm{cpm}-$ spontaneous cpm).

Spontaneous release of ${ }^{51} \mathrm{Cr}$ was measured in wells incubated in medium alone and this was less than $15 \%$ of total ${ }^{51} \mathrm{Cr}$ released from cells dissolved in $5 \%$ Triton $\mathrm{X}-100$ for the same amount of time.

Nitric oxide release. PECs $\left(1 \times 10^{6}\right)$ were incubated on slideflasks (Nunc, Roskilde, Denmark) in $2 \mathrm{ml}$ of phenol red free DMEM with bacterial lipopolysaccharide $(10 \mathrm{ng} / \mathrm{ml})$ and interferon $\gamma(50 \mathrm{U} / \mathrm{ml})$. After $48 \mathrm{~h}$, supernatants were collected and stored at $-20^{\circ} \mathrm{C}$. Nitrite was used as an index of nitric oxide production. Nitrite was detected by the Griess reaction as described previously [26].

Histological examination. Pancreata were fixed with $10 \%$ neutral formaldehyde and embedded in paraffin. These sections were stained with haematoxylin-eosin. Insulitis was scored as follows:

0 , no evidence of insulitis

1 , mononuclear cells occupy $1-25 \%$ of a single islet

$2,26-50 \%$ of a single islet

$3,51-100 \%$ of a single islet

The grade of insulitis was calculated for each mouse as follows:

grade of insulitis $=\Sigma$ score/islet number

The grade was determined by a pathologist who was unaware of the experimental protocol.

Flowcytometric analysis. PECs were analysed by Facscan (Becton Dickinson, Franklin Lakes, NJ, USA) with anti Thy1.2 (pan-T cell), Lyt2(CD8 ${ }^{+}$T cell), L3T4 (CD4 ${ }^{+}$T cell; Becton Dickinson), B220 (RA3 3A1; B-cell) and Mac1 (macrophage; Boehringer Mannheim, Mannheim, Germany) antibodies. 


\section{Statistical analysis}

Numerical data are presented as mean \pm SEM, and statistical analyses were done using the unpaired Student's two-tailed $t$-test. Incidences of diabetes were analysed by the Fisher exact test.

\section{Results}

Cytotoxicity of PEC against P-815. Effector cells were obtained from 12- and 20-week-old NOD mice. Incidences of diabetes were 0 of 0 and 8 of 12 for 12 - and 20 -week-old mice, respectively. Inhibition of thymidine uptake was higher in 20 - than in 12-week-old mice $(55.1 \pm 5.2 \%$, $23.8 \pm 6.5 \%, p<0.01$, respectively) (Fig. 1 ). Some of the non-diabetic and overtly diabetic (blood glucose $>33.3 \mathrm{mmol} / \mathrm{l}$ ) 20-week-old mice showed no cytotoxicity. In the experiments using CY-induced diabetic NOD mice, effector cells were obtained $0,4,8$ and 14 days after CY injection. Mice did not become diabetic until 14 days after the injection (6 of 8). Cytotoxicities of PEC were increased at 8 days post-injection $(31.7 \pm 2.6 \%$ from $18.0 \pm 5.0 \%)$ and further increased at 14 days $(53.2 \pm$ $3.8 \%$ ) (Fig. 2), but mice became diabetic only after 14 days. Flowcytometric analysis showed that macrophages were the main constituents $(50.0 \pm 4.2 \%)$, and were increased in percentage following CY-injection $(63.7 \pm 3.2 \%)$ (Table 1). Control experiments using ICR mice were performed to determine whether CY can enhance the cytotoxicity associated with the development of diabetes. Fourteen days after injection of either $\mathrm{CY}$ or $\mathrm{NaCl}, \mathrm{CY}$-injected NOD mice showed overt diabetes and increased macrophage activity $(p<0.001)$, but ICR mice did not (Fig. 2$)$. These data indicate that PEC increase cytotoxicity against P-815 cells before the development of diabetes.

Macrophage cytotoxicity against MIN6N-9a. Effector cells were obtained from mice which had been injected with $\mathrm{CY}$ or $\mathrm{NaCl} 14$ days earlier. PECs from CY-injected mice were more cytotoxic to MIN6N-9a than those from NaClinjected control mice $(39.7 \pm 6.0 \%$ vs $15.6 \pm 2.2 \%$, at a target:effector ratio of 100:1) (Fig.3). Furthermore, adherent cells (Mac $1+96 \%$ ) had greater cytotoxicity than nonadherent cells (Mac $\left.1{ }^{+} 58 \%\right)(38.6 \pm 3.5 \%$ vs $16.7 \pm 2.8 \%$, at target:effector ratio of 20:1) (Fig. 3). These data suggest that macrophages have cytolytic activity against pancreatic beta cells.

Suppression of macrophages by silica administration (Table 2). Silica administration suppressed the develop- ment of diabetes following CY injection in NOD mice. Histologically, however, the grade of insulitis did not differ. Silica slightly decreased the number of macrophages of PECs (Table 1). In addition, macrophage cytotoxicity against MIN6N-9a, as well as nitric oxide release, was suppressed by silica administration. Based on these results, silica can suppress the development of diabetes through inhibition of nitric oxide secretion from cytotoxic macrophages.

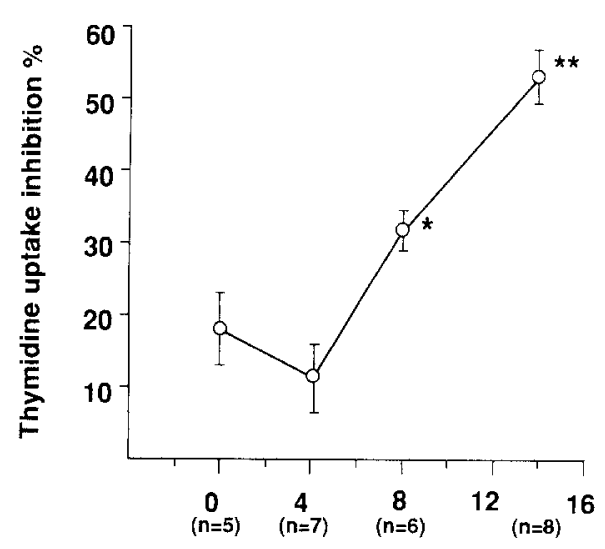

Days after $\mathrm{CY}$ injection

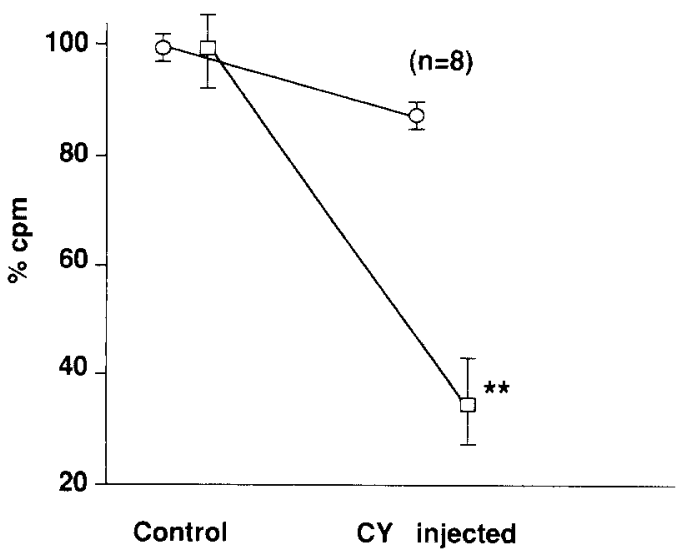

Fig.2. Cytotoxicity of peritoneal exudate cells (PEC) from cyclophosphamide (CY)-injected NOD mice against the P-815 cell. Upper panel: Time course of cytotoxicity after CY-injection. Cytotoxicity was elevated at 8 days post-injection and had increased further at 14 days. Maximal uptake was $455,082 \mathrm{cpm}$. Lower panel: Control study using ICR mice. NOD PEC ( $\square$ ) showed higher cytotoxicity with CY injection than with saline injection, but ICR PEC $(O)$ showed no significant difference. Bars indicate mean \pm SEM. Maximal uptake was $495,659 \mathrm{cpm}$. * $p<0.01$, ** $p<0.001 \mathrm{com}-$ pared to day 0 or control

Table 1. Flowcytometric analysis of peritoneal exudate cells from non-obese diabetic mice injected i.p. with cyclophosphamide (CY) or $0.9 \%$ saline 2 weeks prior to experiment

\begin{tabular}{|c|c|c|c|}
\hline & $\mathrm{CY}(-)$ & CY(+)silica $(-)$ & $\mathrm{CY}(+)$ silica $(+)$ \\
\hline$\overline{n\left(10^{6}\right)}$ & $4.7 \pm 0.7$ & $2.4 \pm 0.2^{b}$ & $3.7 \pm 0.7$ \\
\hline Thy1.2 (pan-T cell) (\%) & $6.4 \pm 1.4$ & $13.1 \pm 3.0^{b}$ & $44.1 \pm 5.9^{c}$ \\
\hline L3T4 (CD4 ${ }^{+} \mathrm{T}$ cell $)$ & $4.5 \pm 1.4$ & $10.2 \pm 2.0^{\mathrm{b}}$ & $25.7 \pm 3.2^{c}$ \\
\hline $\mathrm{B} 220$ (B cell) & $0.5 \pm 0.3$ & $0.8 \pm 2.0$ & $2.9 \pm 2.0^{c}$ \\
\hline Mac1 (Macrophage) & $50.0 \pm 4.2$ & $63.7 \pm 3.2^{\mathrm{a}}$ & $41.5 \pm 4.7^{c}$ \\
\hline
\end{tabular}

${ }^{\mathrm{a}} p<0.05,{ }^{\mathrm{b}} p<0.01$ compared to $\mathrm{CY}(-) ;{ }^{\mathrm{c}} p<0.01$ compared to $\mathrm{CY}(+)$ silica $(-)$ 

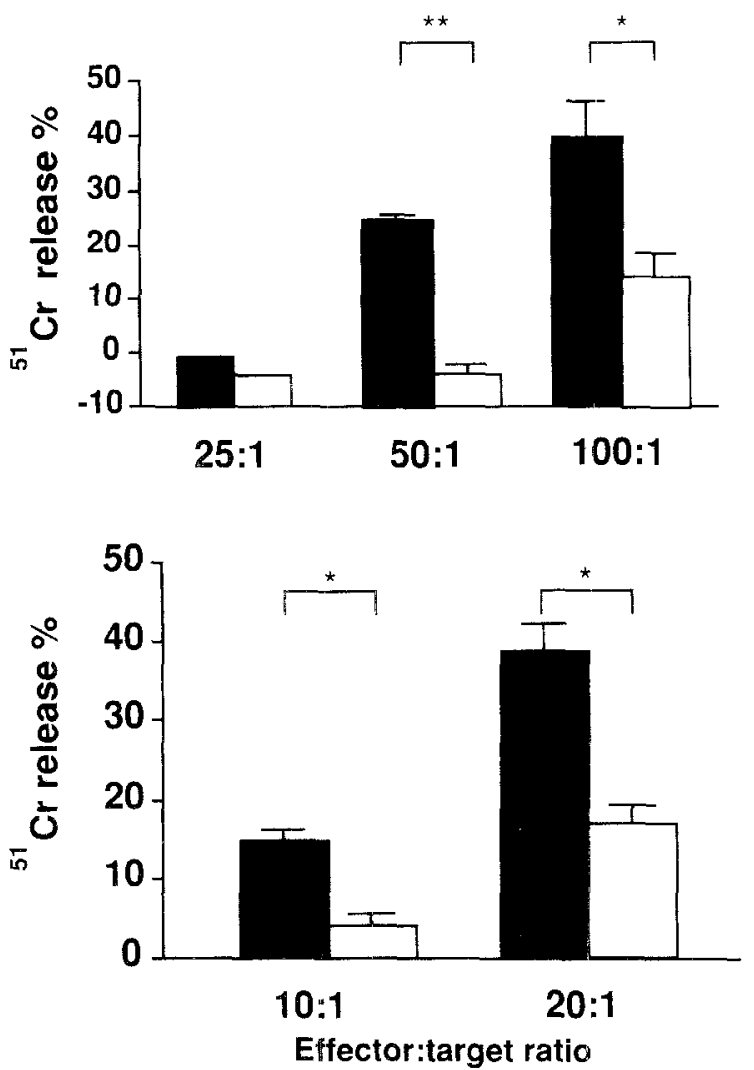

Fig. 3. Cytotoxicity of peritoneal exudate cells (PEC) from cyclophosphamide(CY)-injected NOD mice against MIN6N-9a cell line. Upper panel: PEC from CY-injected mice $(\boldsymbol{m})$ showed higher cytotoxicity than those of $\mathrm{NaCl}$-injected mice $(\square)$. This cytotoxicity increased according to the number of effector cells. $n=6$, bars indicate SEM. Spontaneous and maximal release were 522 and $4015 \mathrm{cpm}$, respectively. ${ }^{*} p<0.01, * * p<0.001$ compared to $\mathrm{NaCl}$-injected mice. Lower panel: Adherent cells $(\square)$ from CY-injected mice showed higher cytotoxicity than non-adherentcells $(\square)$ at each concentration used. $n=5$, bars indicate SEM. Spontaneous and maximal release were 604 and $4474 \mathrm{cpm}$, respectively. ${ }^{*} p<0.01$ was considered significant in comparisons between non-adherent and adherent cells

Table 2. Effects of silica administration from 4 weeks of age on nonobese diabetic mice injected with cyclophosphamide at 12 weeks and cytotoxicity against MIN6N-9a

\begin{tabular}{lcl}
\hline & Silica $(-)$ & Silica $(+)$ \\
\hline Mice, $n$ & 8 & 8 \\
Diabetic mice, $n$ & 8 & $1^{\mathrm{a}}$ \\
Grade of insulitis & $1.75 \pm 0.33$ & $1.07 \pm 0.22$ \\
${ }^{51}$ Cr release $\left.{ }^{\mathrm{c}} \%\right)$ & $13.6 \pm 1.2$ & $1.1 \pm 0.5^{\mathrm{a}}$ \\
Nitrite concentration & $211 \pm 29$ & $161 \pm 43^{\mathrm{b}}$ \\
$\left(\mu\right.$ mol $\left.\cdot 1^{-1} \cdot 48 \mathrm{~h}^{-1} \cdot 10^{6} \mathrm{cells}^{-1}\right)$ & & \\
\hline
\end{tabular}

${ }^{\mathrm{a}} p<0.001,{ }^{\mathrm{b}} p<0.05$ compared to silica $(-)$; ${ }^{\mathrm{c}}$ Target:effector ratio is 100:1, maximal release: $6794 \mathrm{cpm}$, spontaneous release: $724 \mathrm{cpm}$

Cytotoxicity of macrophage-related soluble mediator against MIN6N-9a. Interleukin $1 \beta$, tumour necrosis factor $\alpha$ and sodium nitroprusside, but not interferon $\gamma$, had cytotoxicity against MIN6N-9a cells (Table 3). Although cyanide ions are also produced from nitroprusside, the addition of inactivators of these ions [27], rhodanese

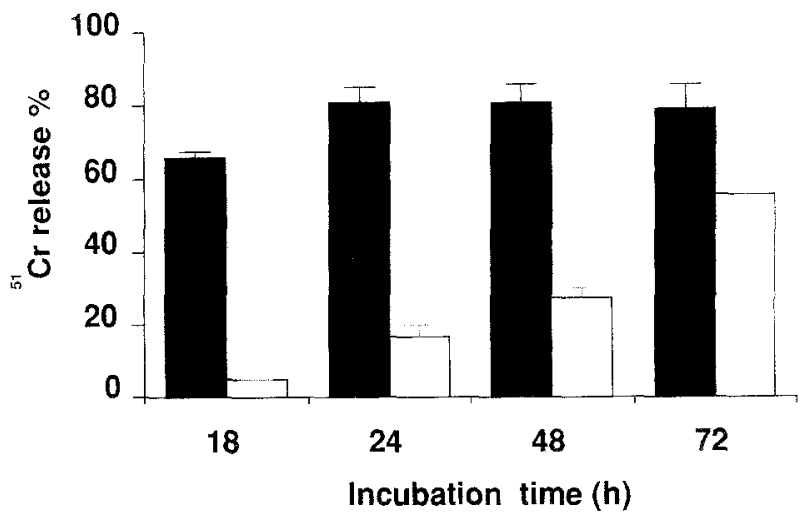

Fig.4. Time course of cytotoxicity against MIN6N-9a cells after exposure to macrophage-related soluble mediator. indicates sodium nitroprusside $(1 \mathrm{mmol} / \mathrm{l})$ and $\square$, interleukin- $1 \beta$ $(10000 \mathrm{U} / \mathrm{ml})+$ tumour necrosis factor $\alpha(10000 \mathrm{U} / \mathrm{ml}) . n=8$, bars indicate SEM

Table 3. Cytotoxicity of macrophage-related soluble factors against MIN6N-9a

\begin{tabular}{llc}
\hline & & Chromium release (\%) \\
\hline Interleukin-1 $\beta$ & $0.1(\mathrm{IU} / \mathrm{ml})$ & $6.7 \pm 2.4$ \\
$(n=6)$ & 1000 & $13.4 \pm 1.8^{\mathrm{a}}$ \\
& 10000 & $13.6 \pm 1.1^{\mathrm{a}}$ \\
Tumour necrosis & 0.1 & $11.8 \pm 3.5$ \\
factor $\alpha(n=6)$ & 1000 & $14.7 \pm 1.6$ \\
& 10000 & $22.6 \pm 1.2^{\mathrm{b}}$ \\
Interferon $\gamma$ & 0.1 & $5.9 \pm 3.5$ \\
$(n=6)$ & 1000 & $4.2 \pm 2.7$ \\
& 10000 & $6.9 \pm 2.7$ \\
Nitroprusside & $0.01(\mathrm{mmol} / 1)$ & $0.1 \pm 0.2$ \\
$(n=12)$ & 0.1 & $26.0 \pm 1.9^{\mathrm{b}}$ \\
& 1 & $53.0 \pm 1.6^{\mathrm{b}}$ \\
\hline
\end{tabular}

${ }^{\mathrm{a}} p<0.05,{ }^{\mathrm{b}} p<0.001$ compared to minimal concentration. Incubation times: $48 \mathrm{~h}$ for cytokines and $18 \mathrm{~h}$ for nitroprusside. Maximal release: $4492 \mathrm{cpm}$, spontaneous release: $538 \mathrm{cpm}$

( 8 units/well) and sodium thiosulphate $(5 \mathrm{mmol} / \mathrm{l})$, did not alter the cytotoxic effects. The cytotoxicity of sodium nitroprusside appeared within $18 \mathrm{~h}$. Cytokines showed cytotoxicity by $48 \mathrm{~h}$ but had no effect at the $18 \mathrm{~h}$ point (Fig.4). Cytokines may not mediate cytotoxicity in this assay.

\section{Discussion}

NOD mice spontaneously develop a diabetic syndrome, which is thought to be attributable to cellular immunity for the following reasons: first, before the onset of diabetes, many mononuclear cells are found in islets of Langerhans, i.e. insulitis develops [1]. Second, transfer examinations have indicated that diabetes can be transferred by injection of spleen $[3,4]$, or peritoneal exudate cells $[22,23]$. Third, disruption of cells participating in cellular immunity, such as T cells [5-7], natural killer cells [8] and macrophages [19-21], can prevent the development of diabetes. 
Macrophages have many functions in cellular im munity, such as antigen presentation, activation and suppression of immune responses and serving as final effector cells of the immune response. Macrophages appear in the early stage of diabetes in NOD mice [28], Biobreeding rats [29] and low-dose streptozotocin-induced diabetic mice [30]. Suppression of macrophage function by administration of silica $[19,20]$ can prevent the development of diabetes. Injection of peritoneal macrophages from diabetic NOD mice can transfer diabetes [22, 23]. Lee et al. [20] concluded that macrophages play an important role in the initiation of insulitis in NOD mice because silica administration can completely prevent insulitis and late silica administration, after 20 weeks, cannot prevent rejection of a transplanted pancreas [31]. However, in our experiment [32], silica completely prevented the development of diabetes, although insulitis was not prevented. Our observations indicate that macrophages also play a role even after insulitis has developed. They may destroy pancreatic beta cells, either alone or in combination with other effector cells. It has been reported that activated macrophages have spontaneous cytotoxicity against pancreatic islet cells [9] and its related soluble factors can destroy pancreatic cells. Because activated macrophages from normal rats were used, the effector role of macrophages in the development of diabetes could not be determined.

Our data indicate that PEC showed increased cytotoxicity against P-815 cells before the development of diabetes in CY-induced diabetic NOD mice. As cytotoxicity against P-815 cells shows only non-specific macrophage activity, we used MIN6N-9a cells as targets. PEC, collected 2 weeks after injection of $\mathrm{CY}$, showed increased cytotoxicity against MIN6N-9a cells, and this cytotoxicity was disrupted by the administration of macrophage toxic silica. Although flowcytometric analysis revealed a small percentage of contaminating T cells, enrichment by adhesion increased the number of macrophages and thereby enhanced cytotoxicity. These data suggest that macrophages have a cytotoxic effect on pancreatic beta cells and may be effector cells mediating the development of diabetes in vivo.

Recently, it has been reported that activated macrophages have strong cytotoxicity against pancreatic islet cells, since the cytotoxicity occurs without direct contact, in a short period of time and at a low effector:target ratio [33], and that cytotoxicity is mediated not via cytokines, but via arginine-dependent nitric oxide generation. Furthermore, NOD mice have a lower ability to produce macrophage-derived cytokines (interleukin and tumour necrosis factor $\alpha)[34,35]$. In vivo injection of tumour necrosis factor $\alpha[34,35]$ actually prevents, rather than enhances, the development of diabetes. In addition, P-815 cells have been reported to be sensitive to nitric oxide [36] and to protease [37]. Thus, we speculate that the macrophage cytotoxicity shown in our assay is mediated via arginine-dependent nitric oxide generation. In our study, tumour necrosis factor $\alpha$, interleukin- $1 \beta$ and a nitric-oxideproducing vasodilator, nitroprusside, were cytotoxic to beta cells, but only nitroprusside was cytotoxic at the end of the 18-h co-incubation period we used for these macro- phage experiments. Therefore, nitric oxide, not cytokines, may mediate this early cytolysis. Nitric oxide is a macrophage-related soluble cytotoxic mediator of pancreatic beta-cell destruction, but it may also be a second mediator of interleukin-1 $[18,38]$, which is secreted from macrophages, in pancreatic beta-cell destruction. The source of nitric oxide during pancreatic beta-cell destruction has not yet been clarified $[39,40]$.

In summary, macrophages play an important role not only in the initiation of insulitis but also in the development of overt diabetes, and may be a final effector cell in beta-cell destruction. In addition, soluble mediators other than cytokines (e.g. nitric oxide) may mediate this early cytolysis.

Acknowledgements. This work was partially supported by a grant from the Ministry of Education, Science and Culture, Government of Japan, and a grant from Keio University School of Medicine.

\section{References}

1. Makino S, Kunimoto D, Muraoka Y, Mizushima Y, Katagiri K, Tochino Y (1980) Breeding of a non-obese diabetic strain of mouse. Exp Anim (Tokyo) 29: 1-13

2. Maruyama T, Takei I, Taniyama M, Kataoka K, Matsuki S (1984) Immunological aspect of nonobese diabetic mice: immune islet cell-killing mechanism and cell-mediated immunity. Diabetologia 27: 121-123

3. Wicker LS, Miller BJ, Mullen Y (1986) Transfer of autoimmune diabetes mellitus with splenocytes from nonobese diabetic (NOD) mice. Diabetes 35: 855-860

4. Miller BJ, Appel MC, O'Neil JJ, Wicker LS (1988) Both the $\mathrm{Lyt}^{+}$and $\mathrm{L} 3 \mathrm{~T} 4^{+} \mathrm{T}$ cells subsets are required for the transfer of diabetes in nonobese diabetic mice. J Immunol 140: 52-58

5. Ogawa M, Maruyama T, Hasegawa T et al. (1985) The inhibitory effect of neonatal thymectomy on the incidence of insulitis in nonobese diabetic (NOD) mice. Biomed Res 6: 103-105

6. Harada M, Makino S (1986) Suppression of overt diabetes in NOD mice by anti-thymocyte serum or anti-Thy1.2 antibody. Exp Anim 35: 501-504

7. Makino S, Harada M, Kishimoto Y, Hayashi Y (1986) Absence of insulitis and overt diabetes in athymic nude mice with NOD genetic background. Exp Anim 35: 495 498

8. Maruyama T, Watanabe K, Takei I et al. (1991) Anti-asialo GM1 antibody suppression of cyclophosphamide-induced diabetes in NOD mice. Diabetes Res 17: 37-41

9. Apples B, Burkart V, Kantwerk-Funke G, Funda J, Kolb-Bachofen V, Kolb H (1989) Spontaneous cytotoxicity of macrophages against pancreatic islet cells. J Immunol 142:3803-3808

10. Wogensen LD, Kolb-Bachofen V, Christensen P et al. (1990) Functional and morphological effects of interleukin- $1 \beta$ on the perfused rat pancreas. Diabetologia 33: 15-23

11. Rabinovitch A, Sumoski W, Rajotte RV, Warnock GL (1990) Cytotoxic effects of cytokines on human pancreatic islet cells in monolayer culture. J Clin Endocrinol Metab 71: 152-156

12. Campbell IL, Iscaro A, Harrison LC (1988) IFN-yand tumor necrosis factor- $\alpha$ cytotoxicity to murine islets of Langerhans. J Immunol 141:2325-2329

13. Sumoski W, Baquerizo H, Rabinovitch A (1989) Oxygen free radical scavengers protect rat islet cells from damage by cytokines. Diabetologia 32: 792-796

14. Nomikos IN, Wand Y, Lafferty KJ (1989) Involvement of $\mathrm{O}_{2}$ radicals in 'autoimmune' diabetes. Immunol Cell Biol 67: 85-87

15. Kroencke KD, Kolb-Bachofen V, Berschick B, Burkart V, Kolb $H$ (1991) Activated macrophages kill pancreatic syngeneic islet cells via arginine-dependent nitric oxide generation. Biochem Biophys Res Commun 175: 752-758 
16. Southern C. Schulter D, Green IC (1990) Inhibition of insulin secretion by interleukin- $1 \beta$ and tumor necrosis factor $\alpha$ via L-arginine-dependent nitric oxide generation mechanism. FEBS Lett 276: 42-44

17. Welsh N, Bendtzen K, Sandler S (1991) Influence of protease on inhibitory and stimulatory effects of interleukin $1 \beta$ on beta-cell function. Diabetes 40: 290-294

18. Rabinovitch A, Baquerizo H, Sumoski W (1990) Cytotoxic effects of cytokine on islet beta-cells: evidence for involvement of eicosanoids. Endocrinology 126: 67-71

19. Charlton B, Bacels A, Mandel TE (1988) Administration of silica particles or anti Lyt 2 antibody prevents beta-cell destruction in NOD mice given cyclophosphamide. Diabetes 37:930-935

20. Lee KU, Amano K, Yoon JW (1988) Evidence for initial involvement of macrophage in development of insulitis in NOD mice. Diabetes 37: 989-991

21. Takei I, Asaba Y, Kasatani T et al. (1992) Suppression of development of diabetes in NOD mice by lactate dehydrogenase virus infection. J Autoimmunity 5: 665-673

22. Horio F, Fukuda M, Hattori M (1990) Peritoneal macrophage can transfer diabetes in NOD mice. Diabetes 39 [Suppl 1]: 394 (Abstract)

23. Shimada A, Takei I, Maruyama T et al. (1992) Transfer of peritoneal macrophages in NOD mice. Diabetes 41 [Suppl 1]:506 (Abstract)

24. Welsh N, Sandler S (1992) Interleukin-1 $\beta$ induces nitric oxide production and inhibits the activity of aconitase without decreasing glucose oxidation rates in isolated mouse pancreatic islets. Biochem Biophys Res Commun 182: 333-340

25. Miyazaki J, Araki K, Yamato E et al. (1990) Establishment of a pancreatic beta cell line that retains glucose-inducible insulin secretion: special reference to expression of glucose transporter isoforms. Endocrinology 127: 126-132

26. Hishikawa K, Nakaki T, Tsuda M et al. (1992) Effect of systemic L-arginine administration on hemodynamics and nitric oxide release in man. Jpn Heart J 33: 41-48

27. Kallmann B, Burkart V, Kroencke KD, Kolb-Bachofen V, Kolb H (1992) Toxicity of chemically generated nitric oxide towards pancreatic islet cells can be prevented by nicotinamide. Life Sci 51: 671-678

28. Signore A, Pozzilli P, Gale EAM, Andreani D, Beverley PCL (1989) The natural history of lymphocyte subsets infiltrating the pancreas of NOD mice. Diabetologia 32: 282-289

29. Walker R, Bone AJ, Cooke A, Baird JD (1988) Distinct macrophage subpopulations in pancreas of prediabetic $\mathrm{BB} / \mathrm{E}$ rats. Diabetes 37: 1301-1304

30. Kolb-Bachofen V, Epstein S, Kiesel U, Kolb H (1988) Low-dose streptozotocin-induced diabetes in mice electron microscopy re- veals single-cell insulitis before diabetes onset. Diabetes 37 : 21-27

31. Ihm SH, Yoon JW (1990) Studies on autoimmunity for initiation of beta-cell destruction. VI. Macrophage essential for development of beta-cell-specific cytotoxic effectors and insulitis in NOD mice. Diabetes 39: 1273-1278

32. Yanagawa T (1990) Immunological study on insulin dependent diabetes. The role of macrophage in the development of diabetes in NOD mouse. Keio Igaku 67: 1032-1038

33. Kroencke KD, Funda J, Berschick B, Kolb H, Kolb-Bachofen V (1991) Macrophage cytotoxicity towards isolated rat islet cells: neither lysis nor its protection by nicotinamide are beta-cell specific. Diabetologia 34: 232-238

34. Jacob CO, Aiso S, Michie SA, McDevitt HO, Orbea HA (1990) Prevention of diabetes in nonobese diabetic mice by tumor necrosis factor (TNF): similarities between TNF- $\alpha$ and interleukin 1. Proc Natl Acad Sci USA 87: $968-972$

35. Satoh J, Seino H, Tanaka S et al. (1989) Recombinant human tumor necrosis factor $\alpha$ suppresses autoimmune diabetes in nonobese diabetic mice. J Clin Invest 84: 1345-1348

36. Higuchi M, Higashi N, Taki H, Osawa T (1990) Cytolytic mechanism of activated macrophages. Tumor necrosis factor and $\mathrm{L}$-arginine-dependent mechanism act synergistically as the major cytolytic mechanism of activated macrophages. J Immunol 144: $1425-1431$

37. LeBlanc PA, Heath LS, Um HD (1990) Activated macrophages use different cytolytic mechanism to lyse a virally infected cell or a tumor target. J Leukocyto Biol 48: 1-6

38. Bergmann L, Kroencke KD, Suschek C, Kolb H, Kolb-Bachofen $\mathrm{V}$ (1992) Cytotoxic action of IL-1 beta against pancreatic islets is mediated via nitric oxide formation and in inhibited by $\mathrm{N}^{\mathrm{G}}$. monomethyl-L-arginine. FEBS Lett 299: 103-106

39. Kolb H, Kolb-Bachofen V (1992) Type 1 (insulin-dependent) diabetes mellitus and nitric oxide. Diabetologia 35: 796-797

40. Corbett JA, McDaniel ML (1992) Does nitric oxide mediate autoimmune destruction of $\beta$-cells? Diabetes 41: 897-903

Received: 8 February 1993

and in revised form: 6 July 1993

Dr. A. Kasuga

Department of Internal Medicine

Keio University

School of Medicine

35 Shinano-machi, Shinjuku-ku

Tokyo 160

Japan 